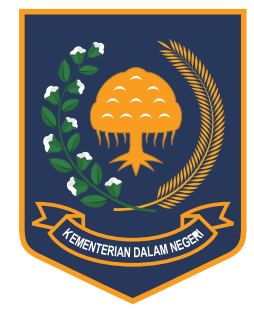

Jurnal Bina Praja 10 (1) (2018): 27-38

Jurnal Bina Praja

e-ISSN: 2503-3360 | p-ISSN: 2085-4323

Accreditation Number

735/AU2/P2MI-LIPI/04/2016

http://jurnal.kemendagri.go.id/index.php/jbp/index

\title{
Evaluation of Budget SPENDing SuStainability of DKI JAKARTA Province's BUDGET
}

\author{
Sri Mahendra Satria Wirawan* \\ Human Resources Development Agency of DKI Jakarta Province \\ Jl. Abdul Muis No. 66, Jakarta Pusat 10160, Indonesia
}

Received: 8 December 2017; Accepted: 16 March 2018; Published online: 12 May 2018

DOI: $10.21787 / j b p .10 .2018 .27-38$

\begin{abstract}
The budget spending in the Regional Government's Budget (APBD) is one of the indicators of the success of the regional development. DKI Jakarta Province's APBD spending is seen to be sub-optimal, with the average of $75.79 \%$ in the last 5 years (2012-2016), below the 95\% target set out by the Minister of Finance. As such, a study is required to review why it happens and what factors need to be addressed to optimize the DKI Jakarta Province's APBD spending. The previous study conducted to analyze the low spending in the Ministries/Institutions and Regional Government in general. This study is conducted to understand the sustainability of the budget spending and to identify the types of spending that might be the driver to optimize the DKI Jakarta Province's APBD spending, enabling the province realized its development target and directly providing a desirable impact the public and the business world, increase their trust to the government and in turn will push the DKI Jakarta's economic growth. This study uses Multidimensional Scaling (MDS) with a secondary data from The Regional Government Financial Report (LKPD) of DKI Jakarta Province for the year of 2012 to 2016 and the End-of-Term Accountability Report (LKPJ-AMJ) of DKI Jakarta Province of the Year 2013 to 2017 (2016a). The result of this study shows that the average DKI Jakarta Province's APBD spending of the last five years (2012-2016) is 47.64 or fall under the category of "less sustainable", whereas the spending items causing the unfavorable result are the social benefits, grants, land acquisitions and buildings and structures spending. As such, it is recommended that the DKI Jakarta Provincial Government establishes a more measurable policy on planning, budgeting and execution and to increase the competence of its apparatus.
\end{abstract}

Keywords: APBD Spending Level, Annual Budget, Multidimensional Scaling (MDS)

\section{INTRODUCTION}

The low rate of budget spending which causes the impediments of public service delivery is a phenomenon that almost always happens every year either at the Ministry/Institution level or the Regional level (Sinaga, 2016, p. 261). DKI Jakarta as an autonomous region based on Law Number 23 of 2014, and also the capital of Indonesia based on Law Number 29 of 2007, is the barometer for other regions in Indonesia. The various problems and strategic issues in the DKI Jakarta Province require serious handling from the Leader, the Jakarta Provincial Government apparatus, the society and business world. To address all existing issues, whether development, upgrading or maintenance, most of the budgeting process is done through the Regional Budget (APBD). As such, the APBD growth is one of development indicators in the economic aspect (Persada, Sitorus, Marimin, \& Djakapermana, 2014, p. 19).

Based on the End-of-Term Accountability Report (LKPJ-AMJ) of DKI Jakarta Governor for the year of 2013-2017 and 2012-2014, the DKI Jakarta Province's Budget (APBD) shows a tendency to increase, however, in 2015 and 2016, it shows a decline. In 2012 it amounted to Rp41.35 trillion, in 2013 amounted to Rp50.26 trillion, in 2014 amounted to Rp72.90 trillion, in 2015 amounted to Rp65.77 trillion and in 2016 amounted to Rp62.91 trillion. In terms of expenditure, the percentage of spending when compared to the plan are as follows: in 2012 was $82.48 \%$, in 2013 was $82.67 \%$, in 2014 was $59.46 \%$, in 2015 was $72.10 \%$ and in 2016 was $82.25 \%$, or an average of $75.79 \%$. Meanwhile, based

\footnotetext{
* Corresponding Author

Phone : +62 85100208556

Email : one_mahendra@yahoo.com
} 
on the provisions in the Regulation of the Minister of Finance Number 258 of 2015, the indicator of success of the budget spending is above $95 \%$.

With the issuance of Government Regulation Number 58 of 2005 on Regional Financial Management followed by the issuance of Regulation of the Minister of Home Affairs of the Repulic of Indonesia Number 13 of 2006 regarding Guidelines on Regional Financial Management that amended by Regulation of the Minister of Home Affairs Number 21 of 2011 a fundamental change in the preparation of the regional budget using a performancebased budgeting approach is introduced in the hope of improving government's efficiency and public services and increasing public trust in the government (Hill \& Andrews, 2005, p. 257).

Based on the data published by the Statistics of DKI Jakarta Province (BPS Provinsi DKI Jakarta) (2017), the DKI Jakarta's economic growth based on its Regional GDP shows that the trend continues to slow, from $6.53 \%$ in 2012 , next $6.07 \%$ in 2014 , then $5.91 \%$ in 2015 , to $5.89 \%$ by 2015 , and $5.85 \%$ by 2016 . DKI Jakarta's Regional GDP comprised of Household and Institution Consumption Expenditure (59.48\%), Non-Profit Institution serving the household (1.84\%), Government Consumption (12.70\%), Non-Military Capital expenditure ("Pembentukan Modal Tetap Bruto (PMTB)) 42.80\%, Inventory Changes $0.63 \%$, as well as the difference between Foreign Imports and Exports and Inter-Regional Nett Export (17.45\%). The average contribution of government expenditure to the Regional GDP of DKI Jakarta for the five years from 2012 to 2016 is $12.70 \%$, consisting of $13.38 \%$ contribution in 2012 , $13.66 \%$ in $2014,12.63 \%$ in $2015,12.07 \%$ in 2015 , and $11.77 \%$ in 2016 .

The previous studies concluded that there is a significant influence between government spending and regional economic growth in Indonesia, as well as in Java and Bali (Anitasari \& Soleh, 2012, p. 126; Haryanto, 2013, p. 156; Hidayat \& Nalle, 2017, p. 84), especially those related to capital expenditures (Hakim \& Wijayanti, n.d., p. 14), as such, although the DKI Jakarta's government expenditures only contributes $12.70 \%$ to its GDP, it is considered to be a driver of economic growth in DKI Jakarta. Through government spending, the city infrastructures can be built and maintained, educational, health and other public services can be improved, so that the public's confidence in the government may increase. With the increase of public confidence in the government, the business climate flourish and the private and corporate investment may be increased. With the increase in private and business investment, more employment and business opportunities for communities may be available, resulting in the increase of the community income. Furthermore, the improvement of public infrastructure facilities in all sectors undertaken by the government through APBD spending will surely also be able to increase direct exports from Jakarta as well as those coming from outside Jakarta but through Jakarta.

Various studies were conducted in an effort to optimize and increase the budget spending, some previous research related to APBD was focusing on institutional aspects and process at the APBD implementation stage.

Kuncoro (2008, p. 141) who examines the variations in the budget and its realization in the case study of the Provincial Government of DKI Jakarta's budget, concludes that there is a significant difference in the budget of the 2004-2007 period.

Puspitasari (2013, p. 367) through her research on performance-based budgeting studies at the provincial governments of East Java, West Java, and DKI Jakarta, concludes that the main issue that still needs to be evaluated is the issue of procurement of goods and services and the regional leadership. The slow spending of the budget is often associated with the prolonged process of procurement of goods and services.

Duadji (2013, p. 202) in his study titled Public Participation in Decision Making of the Regional Budget of Lampung Province, concluded that Decision Making is still seen as a political process and as political transaction and bargaining medium for the elite. Procedural matters are the main and more important matters, while content as the embodiment of public interest is not a priority.

Benacorry \& Bachtiar (2014, p. 22) in their study on the analysis of changes in APBD compilation process in the DKI Jakarta Provincial Government, concluded that the change of APBD compilation from the Information Planning System to e-Budgeting resulted in the delay of determination of the APBD which in turn affect the low spending of the budget.

Meanwhile, Wijayanto (2015, p. 87) in his study related to the transparency of the Regional Budget through the implementation of e-budgeting (in the perspective of Good Governance theory), concluded that in essence, the value transformation in this reform era is in the increasing emphasis on public accountability processes, transparency of government agenda, and openness of budgetary allocations, especially for regional government officials, regardless of vertical accountability to the central government in all aspects of government. Government policies such as e-budgeting are dependent on other aspects. Its success depends on effectiveness, transparency, and effective management of human resource management (HR), especially the ability of public resources at the government level.

In contrast to Wijayanto, Sinaga (2016, p. 272) has conducted a study on the analysis of the 
low budget spending in the Ministries/Institutions and Regional Government with the conclusion that to accelerate the spending of the state budget, a regulation, which gives more trust to the executives to be more flexible in using budget while maintaining the principles of effectiveness, efficiency, and accountability, is necessary.

A concept developed by Pitcher \& Preikshot (2001, p. 268) stated that the aspect of sustainability includes ecological, economic, social and technological aspects with its various attributes, while Jenssen, Vråle \& Lindholm (2007, p. 3) stated that sustainability should include ecological, economic and social aspects. Sustainability can also be applied to other sectors, not only to development and environmental issues. The study conducted by Simarmata (2007, p. 3) highlights the fiscal sustainability issues related to government debt levels, as such, it can also be said to be the sustainability of government debt. Sustainability is defined as the ability to maintain existing macroeconomic policies without the threat of a crisis.

It is understandable that sustainability can be defined as a "balance" to be maintained, in APBD spending, the balance to be maintained is between various component of spending, as a unit to be viewed holistically ie, personnel, goods and services, interest and subsidies, grants, social assistance, land acquisitions, equipment and machineries, building and structures, roads, irrigation and network, and other fixed asset expenditures.

Therefore, this study is important to be performed since, in contrast to previous studies, this study is focused on the output of the APBD implementation, which is the component of spending as the internal performance measurement in the APBD. As such the efforts to optimize APBD spending can be done comprehensively to identify the sustainability of the DKI Jakarta's APBD spending, as well as identifying the elements that can be its leverage, to enable development of the strategy to manage and improve the spending performance of DKI Jakarta's APBD.

\section{METHOD}

The study was conducted in November 2017, on the execution of DKI Jakarta's APBD in the year of 2012 to 2016, while the study location is DKI Jakarta Province.

The APBD spending's data is obtained from secondary data published in (1) The Regional Government Financial Report (LKPD) of DKI Jakarta Province of 2012, (2) The Regional Government Financial Report (LKPD) of DKI Jakarta Province of 2013, (3) The Regional Government Financial Report (LKPD) of DKI Jakarta Province of 2014, (4) The Regional Government Financial Report
(LKPD) of DKI Jakarta Province of 2015, (5) The Regional Government Financial Report (LKPD) of DKI Jakarta Province of 2016, 6) End-of-Term Accountability Report (LKPJ-AMJ) of the Governor of DKI Jakarta Province of 2013 - 2017. The data was then examined to establish attributes based on groups and types of expenditures referring to the provisions in the Regulation of the Minister of Home Affairs of the Repulic of Indonesia Number 13 of 2006 (2006), which are: (1) personnels, (2) goods and services, (3) interests and subsidies, (4) grants, (5) social assistances, (6) land acquisitions, (7) equipment and machinery, (8) buildings and structures, (9) roads, irrigation and network, (10) other fixed assets.

The method used in this study is multidimensional scaling (MDS) which is one of the multiple variable techniques that can be used to determine the position of another object based on its similarity assessment. As the development of the rapfish approach used to assess the status of development sustainability, Roy (1982, p. 244) state that MDS techniques can be used for decision making in urban, regional, architectural, resource management, and others with a reliable result, enabling a decision-making process which would produced a significant advantage.

Several studies from various fields have been widely used using the MDS method (Bakeri, P., Riani, \& Sutjahjo, 2012, p. 15; Hikmah, Yulisti, \& Nasution, 2011, p. 105; Nurmalina, 2008, p. 67; Rismunandar, 2016, p. 188; Walundungo, Paendong, \& Manurung, 2014, p. 31; Widiatmaka, Munibah, \& Sitorus, 2015, p. 116; Yogiesti, Hariyani, \& Sutikno, 2010, p. 96).

MDS is an approach that gives stable results compared with other the multidimensional method, and able to transforms the multi-dimension into a simpler dimension (Pitcher \& Preikshot, 2001, p. 256). To determine a point that may reflect the continuity of two reference points with the categories of good and bad, all data from the attributes used are analyzed multidimensionally. According to Fauzi \& Anna (2005, p. 265), the MDS on Rapfish is applied by calculating the shortest distance from the multidimensional space of two points, then be projected into a two-dimensional distance. The regression applies the lscal algorithm by the iteration process to get the smallest error value.

In MDS, two points or the same object are mapped as points that are close to each other. Conversely, dissimilar objects or points are illustrated with far apart points, so it is useful to calculate the stress function in the regression analysis in the MDS method. The matrix X (n $\mathrm{x}$ p) will be formed based on the value of each attribute, where $n$ is the research object along with its reference points, while $p$ is the number of 
attributes used. The value for each attribute is then standardized so that the differences between the scales measurement scales can be omitted and each attribute has a uniform weight.

According to Fauzi \& Anna (2005, p. 265), the MDS on Rapfish is applied by calculating the nearest Euclidean distance in the following equation:

$$
d_{12}=\sqrt{\left(x_{1}-x_{2}\right)^{2}+\left(y_{1}-y_{2}\right)^{2}}+\ldots
$$

The multidimensional Euclidean distance between the two points $\left(d_{12}\right)$ is then projected into the two-dimensional Euclidean distance $\left(D_{12}\right)$ based on the regression formula in the following equation:

$$
d_{12}=a+b D_{12}+e \text {; where } e \text { is error }
$$

The regression applies the lscal algorithm with an iteration process to get the smallest error value. According to Kavanagh (2001), the alscal algorithm applied forces the intercept value to the equation to be zero, so that the regression equation changes to the following equation:

$$
d_{12}=b D_{12}+e
$$

The iteration process stops if the stress value <; 0.25 , as defined in the following equation:

$$
\text { Stress }=\sqrt{\frac{I}{m} \sum_{k=1}^{m}\left[\frac{\sum_{i} \sum_{j}\left(D_{i j k}-d_{i j k}\right)^{2}}{\sum_{i} \sum_{j} d_{i j k}^{2}}\right]}
$$

The stress value is the square root of stress value so the stress value can also be obtained by the following formula:

$$
\text { Stress }=\frac{\text { MSSe }_{i j k}}{\text { MSSd }_{i j k}}
$$

\section{where MSS is mean sum square}

A good model shows the Stress value <; 0.25 and $R^{2}$ almost 1 . The sustainability index scale has a 0-100 interval. This study uses four sustainability status categories as shown in Table 1.

Another result obtained in the MDS analysis is the leverage factor as the result of leverage analysis that is a strategic factor in future management activities. The leverage analysis aims to see the change in the error from determining the value of sustainability if one of the attributes is excluded from
Table 1.

Sustainability Status Categories

\begin{tabular}{cc} 
Index Value & Categories \\
$0-25$ & Poor (not continous) \\
\hline $25-50$ & Less (less sustainable) \\
\hline $51-74$ & Enough (quite sustainable) \\
\hline $75-100$ & Good (very sustainable) \\
\hline
\end{tabular}

Source: Kavanagh (2001)

the analysis. According to Pitcher (1999, p. 11), the leverage analysis or sensitivity analysis is performed on all attributes of each dimension. The calculation is performed by the stepwise method, which is to remove each attribute individually one by one and then calculate the error or root mean square (RMS) value compared to the RMS value generated when all attributes are analyzed. This method is known as the jackknife method (Kavanagh, 2001, p. 11). The evaluation of the effect of an error on the process of predicting the ordnance value of sustainability status analysis is performed by using the Monte Carlo analysis.

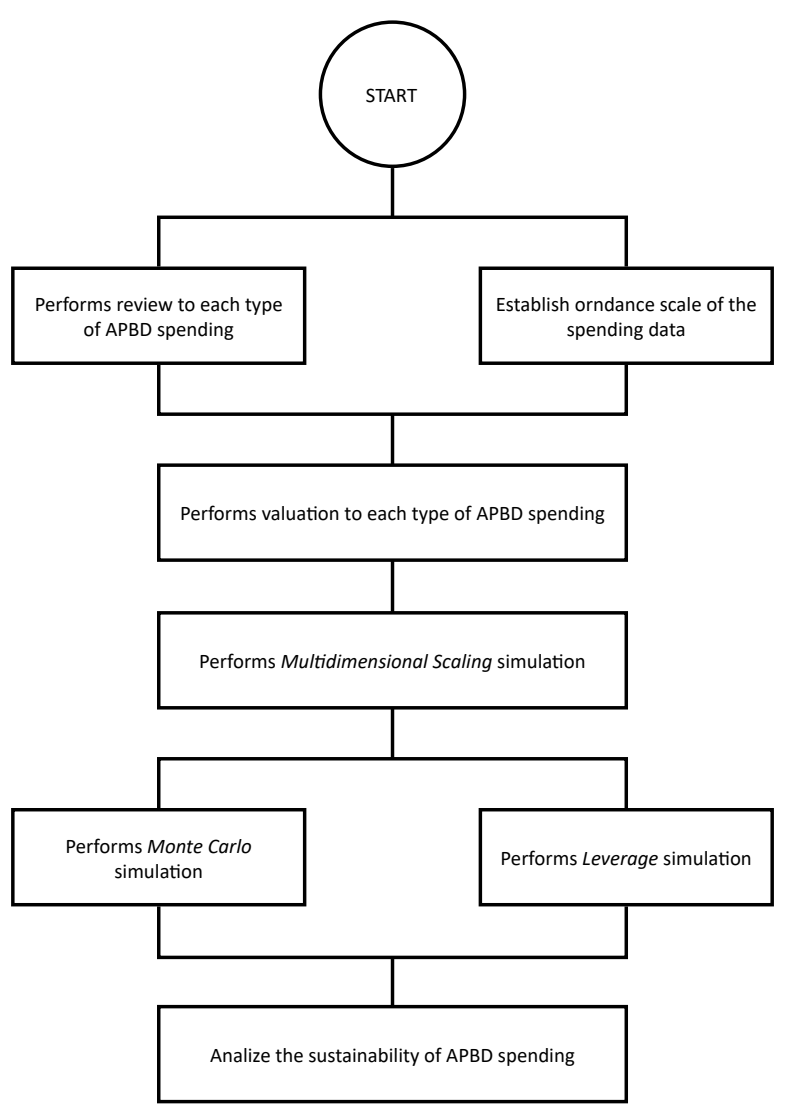

Figure 1. Analysis process of the sustainability of APBD spending 
The MDS method with Rap-Budget Spending which is a modification of Rapfish is used to assess the sustainability of DKI Jakarta's APBD spending. The Rap-Budget Spending analysis is performed in these stages : 1) reviews the spending of each type of APBD, (2) arranges the scale of each type of spending using ordinal scale of 1 to 5 , with the lowest criterion 1 is for spending below $55.00 \%$, while the highest value of 5 is for spending above $95.00 \%$ (as stipulated in the Regulation of the Minister of Finance Number 258 of 2015 on the Procedure for Awarding and Imposing Sanctions on the Implementation of Expenditures of Ministries/ Institutions) (3) performs a valuation of the spending type, (4) performs the multidimensional scaling simulation to determine the index value, sustainability status and stress value, (6) performs the leverage simulation to determine sensitive variables affecting the sustainability of DKI Jakarta's budget spending and (7) performs the Monte Carlo simulation to account for the uncertain aspects (8) performs the sustainability analysis of the spending (Kavanagh, 2001, p. 11; Pitcher \& Preikshot, 2001, p. 269). The analysis performed on the spending data of each type of budget for each simulation (Multidimensional, Leverage and Monte Carlo) was using the Rapfish program which is modified into Rap-Budget Spending using Microsoft Excel. Overall, the data processing process can be seen in Figure 1.

\section{RESULTS AND DISCUSSION}

\section{A. Budget Spending Data}

In detail, data on the DKI Jakarta's APBD spending in the period of 2012-2016 for each type of expenditure can be seen in Table 2 .

Table 2.

APBD DKI in 2012-2016 Spending

\begin{tabular}{|c|c|c|c|c|}
\hline \multirow{2}{*}{ No } & \multirow{2}{*}{ Type } & \multicolumn{3}{|c|}{2012} \\
\hline & & Plan & Realization & $\%$ \\
\hline 1 & Personnel & $11,896,841,165,160$ & $11,085,950,169,778$ & 93.18 \\
\hline 2 & Goods & $11,383,664,759,250$ & $9,703,452,918,759$ & 85.24 \\
\hline 3 & Interest and Subsidies & $4,353,828,000$ & $3,172,974,470$ & 72.88 \\
\hline 4 & Grants & $2,089,282,239,330$ & $1,933,097,203,700$ & 92.52 \\
\hline 5 & Social Assistances & $29,470,000,000$ & $15,993,940,302$ & 54.27 \\
\hline 6 & Land & $2,189,409,817,529$ & $493,714,536,473$ & 22.55 \\
\hline 7 & Equipment and Machineries & $4,022,430,078,390$ & $3,262,969,992,000$ & 81.12 \\
\hline 8 & Buildings and Structures & $3,119,395,559,863$ & $2,527,761,153,328$ & 81.03 \\
\hline 9 & Roads, Irrigations, and Networks & $2,815,865,912,275$ & $1,961,671,907,869$ & 69.66 \\
\hline \multirow[t]{2}{*}{10} & Other Fixed Assets & $672,627,883,235$ & $538,248,170,756$ & 80.02 \\
\hline & Amount & $38,223,341,243,032$ & $31,526,032,967,435$ & 82.48 \\
\hline \multirow{2}{*}{ No } & \multirow{2}{*}{ Type } & \multicolumn{3}{|c|}{2013} \\
\hline & & Plan & Realization & $\%$ \\
\hline 1 & Personnel & $13,259,773,060,930$ & $11,861,669,179,762$ & 89.46 \\
\hline 2 & Goods & $14,610,823,722,041$ & $12,641,399,413,173$ & 86.52 \\
\hline 3 & Interest and Subsidies & $4,353,828,000$ & $2,191,752,114$ & 50.34 \\
\hline 4 & Grants & $2,231,650,260,000$ & $1,999,968,587,301$ & 89.62 \\
\hline 5 & Social Assistances & $1,277,394,740,000$ & $1,044,598,129,405$ & 81.78 \\
\hline
\end{tabular}




\begin{tabular}{|c|c|c|c|c|}
\hline 6 & Land & $2,234,948,276,655$ & $749,179,258,197$ & 33.52 \\
\hline 7 & Equipment and Machineries & $6,546,196,108,599$ & $4,953,305,974,019$ & 75.67 \\
\hline 8 & Buildings and Structures & $3,075,686,362,983$ & $2,714,322,488,763$ & 88.25 \\
\hline 9 & Roads, Irrigations, and Networks & $1,890,588,378,802$ & $1,464,462,609,554$ & 77.46 \\
\hline \multirow[t]{2}{*}{10} & Other Fixed Assets & $1,132,184,251,292$ & $814,741,863,779$ & 71.96 \\
\hline & Amount & $46,263,598,989,302$ & $38,245,839,256,067$ & 82.67 \\
\hline \multirow{2}{*}{ No } & & \multicolumn{3}{|c|}{2014} \\
\hline & Type & Plan & Realization & $\%$ \\
\hline 1 & Personnel & $15,976,325,609,617$ & $12,604,588,791,793$ & 78.90 \\
\hline 2 & Goods & $18,096,459,409,318$ & $12,624,396,750,887$ & 69.76 \\
\hline 3 & Interest and Subsidies & $4,353,828,000$ & $1,218,528,851$ & 27.99 \\
\hline 4 & Grants & $2,714,824,096,501$ & $1,462,044,387,771$ & 53.85 \\
\hline 5 & Social Assistances & $1,220,977,869,500$ & $680,155,340,000$ & 55.71 \\
\hline 6 & Land & $6,938,606,031,044$ & $1,754,586,883,131$ & 25.29 \\
\hline 7 & Equipment and Machineries & $7,635,472,477,300$ & $4,062,228,522,758$ & 53.20 \\
\hline 8 & Buildings and Structures & $4,949,591,757,230$ & $2,589,956,270,028$ & 52.33 \\
\hline 9 & Roads, Irrigations, and Networks & $4,756,735,388,047$ & $1,599,630,901,228$ & 33.63 \\
\hline \multirow[t]{2}{*}{10} & Other Fixed Assets & $1,250,225,047,040$ & $404,715,813,104$ & 32.37 \\
\hline & Amount & $63,543,571,513,597$ & $37,783,522,189,551$ & 59.46 \\
\hline \multirow{2}{*}{ No } & & \multicolumn{3}{|c|}{2015} \\
\hline & & Plan & Realization & $\%$ \\
\hline 1 & Personnel & $19,505,273,188,832$ & $17,312,344,016,739$ & 88.76 \\
\hline 2 & Goods & $16,421,400,772,993$ & $10,633,820,105,891$ & 64.76 \\
\hline 3 & Interest and Subsidies & $940,046,070,052$ & $664,560,474,871$ & 70.69 \\
\hline 4 & Grants & $1,785,249,464,211$ & $1,717,428,915,536$ & 96.20 \\
\hline 5 & Social Assistances & $2,088,011,505,000$ & $2,087,123,200,000$ & 99.96 \\
\hline 6 & Land & $7,357,852,305,531$ & $3,451,775,763,772$ & 46.91 \\
\hline 7 & Equipment and Machineries & $3,218,039,451,093$ & $2,002,190,574,946$ & 62.22 \\
\hline 8 & Buildings and Structures & $3,414,624,665,827$ & $2,063,978,323,661$ & 60.45 \\
\hline 9 & Roads, Irrigations, and Networks & $4,334,484,447,777$ & $2,685,243,694,385$ & 61.95 \\
\hline 10 & Other Fixed Assets & $100,711,708,033$ & $40,828,352,444$ & 40.54 \\
\hline & Amount & $59,165,693,579,349$ & $42,659,293,422,245$ & 72.10 \\
\hline
\end{tabular}




\begin{tabular}{|c|c|c|c|c|}
\hline \multirow{2}{*}{ No } & \multirow{2}{*}{ Type } & \multicolumn{3}{|c|}{2016} \\
\hline & & Plan & Realization & $\%$ \\
\hline 1 & Personnel & $21,484,497,759,347$ & $9,359,807,013,530$ & 90.11 \\
\hline 2 & Goods & $16,812,849,152,875$ & $13,062,670,779,326$ & 77.69 \\
\hline 3 & Interest and Subsidies & $1,365,426,275,800$ & $915,638,014,264$ & 67.06 \\
\hline 4 & Grants & $2,248,455,193,332$ & $2,161,217,950,484$ & 96.12 \\
\hline 5 & Social Assistances & $2,503,493,425,000$ & $2,452,948,130,000$ & 97.98 \\
\hline 6 & Land & $3,032,948,358,774$ & $1,970,939,912,239$ & 64.98 \\
\hline 7 & Equipment and Machineries & $2,288,861,798,125$ & $1,780,464,137,977$ & 77.79 \\
\hline 8 & Buildings and Structures & $2,649,835,256,840$ & $1,687,059,996,551$ & 63.67 \\
\hline 9 & Roads, Irrigations, and Networks & $4,351,189,733,684$ & $3,287,656,766,815$ & 75.56 \\
\hline \multirow[t]{2}{*}{10} & Other Fixed Assets & $303,312,158,476$ & $239,349,200,951$ & 78.91 \\
\hline & Amount & $57,040,869,112,253$ & $46,917,751,902,137$ & 82.25 \\
\hline
\end{tabular}

\section{B. Determination and Valuation of Spending Type}

The overall valuation of DKI Jakarta's APBD spending type are shown in Table 3.

Table 3.

Valuation of the Type of Spending

\begin{tabular}{cc} 
Amount & Budget Spending Data (\%) \\
\hline 5 & $95-100$ \\
\hline 4 & $85 \leq 95$ \\
\hline 3 & $75 \leq 85$ \\
\hline 2 & $65 \leq 75$ \\
\hline 1 & $0 \leq 65$ \\
\hline
\end{tabular}

The DKI Jakarta's APBD spending for the period of 2012 to 2016 is in the range of $75.79 \%$, with macroeconomic growth continuously slowing down. The result of this study shows the index and sustainability status of the APBD's spending and is expected to explain what has happened during the period of 2012-2016.

\section{1) Rap-Budget Spending Analysis}

The result of Rap-Budget Spending analysis by using the MDS method generates the sustainability index of DKI Jakarta's budget spending in multiple dimensions, with an average value of 47.64 on sustainability scale of 0 to 100 . It means DKI Jakarta's sustainability index falls in the range of 25-50 or "less sustainable". The complete results of MDS analysis are presented in Table 4.

Referring to the sustainability status in Table 1 , it can be seen that for indirect expenditure group consisting of personnel, interest and subsidies, grants and social assistance, the average sustainability index is 46.46 . The capital expenditure group consisting of land, equipment, and machinery, buildings and structures, roads, irrigation and network, and other fixed asset expenditures are at an average sustainability index of 48.93. While for the group of goods/ services expenditure, the sustainability index is 46.60 . Overall, all types the DKI Jakarta's APBD spending is in the category of "less sustainable" Detail of the sustainability Index of DKI Jakarta's Spending for the period of 20122016 are presented in Table 5.

For the period of five years from 2012 to 2016, the distribution DKI Jakarta's budget spending sustainability index based on the multidimensional Rap-Budget Spending analysis shows that its sustainability index is in the range of 30 to 60 , as shown in Figure 2.

Based on the distribution of sustainability status, the DKI Jakarta's budget spending sustainability model is divided into two groups, those with "less sustainable" status (2012, 2014 and 2015) and those with "enough sustainable "status (2013 and 2016). The lowest sustainability index value is occurring in 2014, with a score of 34.02, under the category of "less sustainable". While the highest is the sustainability index in 2016, with 
Table 4.

Result of MDS Analysis

\begin{tabular}{lllllll}
\multicolumn{1}{r}{ Type of Spending } & \multicolumn{7}{c}{ Sustainability Index of } & Average \\
Personnel & $\mathbf{2 0 1 2}$ & $\mathbf{2 0 1 3}$ & $\mathbf{2 0 1 4}$ & $\mathbf{2 0 1 5}$ & $\mathbf{2 0 1 6}$ & 46.24 \\
\hline Goods & 48.57 & 52.23 & 31.87 & 44.54 & 53.97 & 46.60 \\
\hline Interest and Subsidies & 48.02 & 51.73 & 31.98 & 46.71 & 54.56 & 48.28 \\
\hline Grants & 49.57 & 54.71 & 34.16 & 46.76 & 56.20 & 45.11 \\
\hline Social assistances & 47.28 & 51.02 & 34.49 & 41.66 & 51.09 & 46.23 \\
\hline Land & 51.81 & 52.64 & 34.74 & 41.17 & 50.81 & 50.31 \\
\hline Equipment and Machineries & 51.89 & 55.84 & 34.77 & 50.17 & 58.87 & 48.36 \\
\hline Buildings and Structures & 48.56 & 52.48 & 34.78 & 50.52 & 55.45 & 48.61 \\
\hline Roads, Irrigations and Networks & 48.85 & 51.33 & 34.76 & 50.17 & 57.95 & 48.69 \\
\hline Other Fixed Assets & 49.99 & 52.97 & 34.76 & 49.79 & 55.93 & 48.68 \\
\hline Multidimension & 49.93 & 53.34 & 34.59 & 49.21 & 56.32 & $\mathbf{4 7 . 6 4}$
\end{tabular}

Table 5.

Multidimensional Sustainability Index

\begin{tabular}{ccc} 
& \multicolumn{2}{c}{ Sustainability } \\
Year & Index & Status \\
2012 & 49.36 & Less \\
\hline 2013 & 52.78 & Enough \\
\hline 2014 & 34.02 & Less \\
\hline 2015 & 47.05 & Less \\
\hline 2016 & 55.02 & Enough \\
\hline
\end{tabular}

a score of 55.02, under the category of "enough sustainable" status. The comparison of DKI Jakarta's APBD spending sustainability for the period of 2012 to 2016 is shown in the kite diagram in Figure 3.

As explained in the previous discussion, the MDS analysis resulting in the stress value of 0.17 . The stress value shows that the pressure on the budget spending model is relatively small, since it is still below 0.25 , and it can be stated that the data used are good and the error effect on the assessment of an attribute is very small and can be ignored. Thus, this model is quite significant to explain the sustainability of the DKI Jakarta's APBD spending. The R2 value of 0.94 , close to 1 , indicates that there is close correlation between the various types of expenditures in a dimension, or it can be said that the sustainability index of the DKI Jakarta's APBD spending can be explained by the type of expenditure used, while the rest is explained by other attributes not examined in this study.

\section{2) Leverage Analysis}

The result of the sustainability leverage analysis indicates that there are four types of significant spending that are sensitive to affect the performance of the DKI Jakarta's budget spending, which are social assistance, grants, land acquisitions and buildings and structures expenditure. The social assistance expenditure

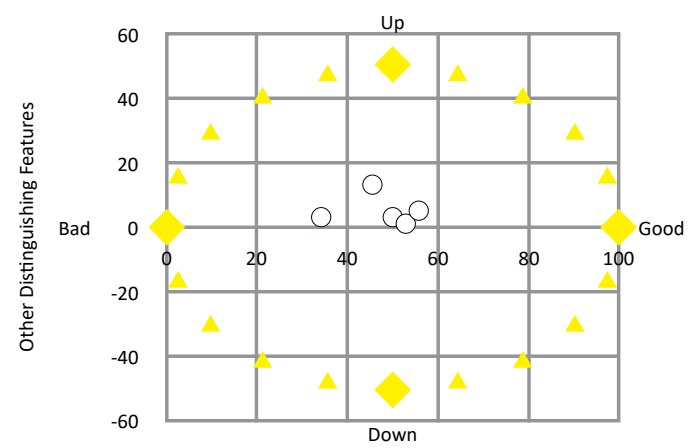

Figure 2. The Distribution of Spending Sustainability 


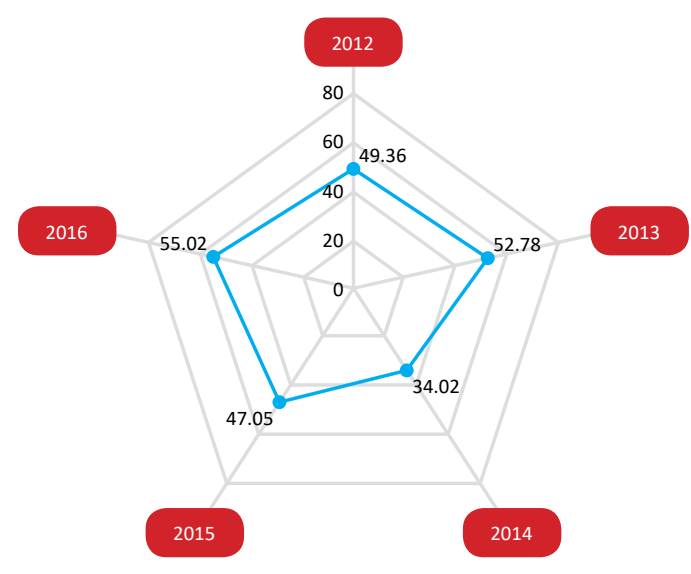

Figure 3. Spending Sustainability Diagram

has a great impact to provide access for the poor to finance their economic activities to improve their welfare. Grants granted to non-governmental organizations, as well as government agencies to date are still indispensable undertakings. Grants for non-governmental organizations or institutions that contribute positively to the implementation of governance and public services are still needed by the DKI Jakarta Government. Grants also still needed to overcome the limitations of government agencies budget, either for vertical government agencies such as the TNI and Police to assist the security and
Table 6.

The Comparison of the MDS Analysis with the Monte Carlo Analysis

\begin{tabular}{cccc} 
Year & MDS & $\begin{array}{c}\text { Monte } \\
\text { Carlo }\end{array}$ & Difference \\
2012 & 49.36 & 49.07 & 0.29 \\
\hline 2013 & 52.78 & 52.84 & 0.06 \\
\hline 2014 & 34.02 & 33.21 & 0.81 \\
\hline 2015 & 47.05 & 46.36 & 0.68 \\
\hline 2016 & 55.02 & 54.56 & 0.46 \\
\hline Average & 47.64 & 47.21 & 0.44
\end{tabular}

order of the capital, or the horizontal government agencies within the scope of Jabodetabekjur region as an effort to establish regional cooperation based on equality and mutually beneficial cooperation. Land acquisition expenditure is also a crucial factor in increasing infrastructure development, as almost all development and infrastructure expansion plans are highly dependent on the availability of land. The building and structure expenditure has been facing many obstacles in the auction process, which delays the budget spending and thus in turn delays the

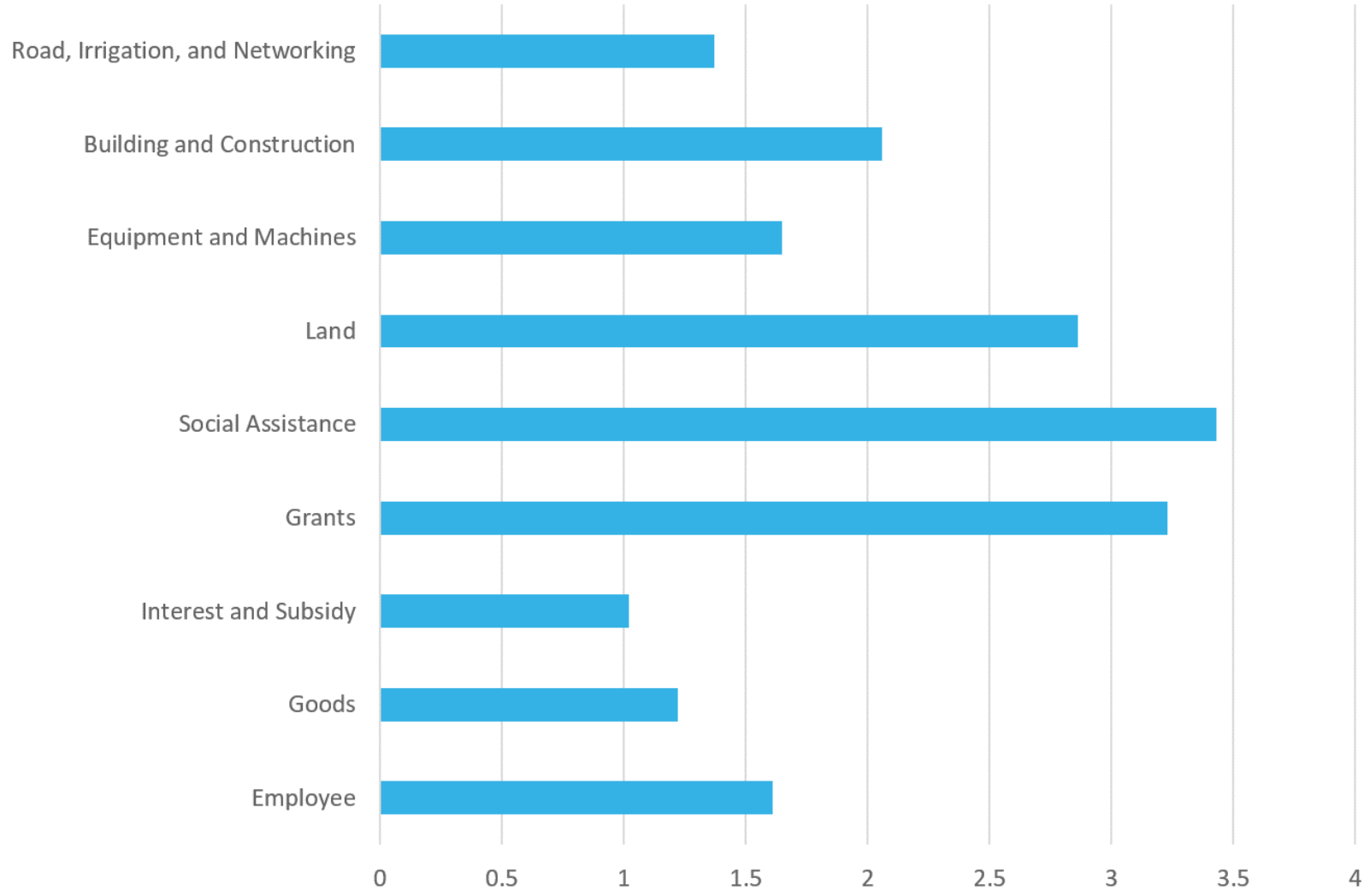

Figure 4. The Leverage Factors on the Budget Spending 
completion time. As for other types of expenditures that are not significant, the government still need to maintain the spending pattern to maintain the sustainability index.

The types of the dominant and significant expenditure leverage on the sustainability of DKI Jakarta's budget spending are described in Figure 4.

\section{3) Monte Carlo Analysis}

Based on the Monte Carlo analysis, the average sustainability of DKI Jakarta's APBD spending for the period of $2012-2016$ is 47.21 with $95.00 \%$ confidence interval, while the MDS analysis resulting to an average of sustainability of budget spending of 47.64. The difference between the two is relatively small $(0.44$ or $0.92 \%)$, less than $5.00 \%$. In other words, the level of confidence in the resulting sustainability index is more than 95.00\% This means that the resulting MDS analysis model is adequate (Widiatmaka et al., 2015), in this study, it means that it is sufficient to estimate the sustainability of the DKI Jakarta's ABPD spending. The Comparison of the MDS analysis with the Monte Carlo analysis is described in Table 6.

The sustainability index also indicates that the errors in the scoring of each type of expenditure are relatively small, the variety of scores due to the difference in opinion is relatively small, the repeated analysis process is stable, and data entry errors and lost data can be avoided (Pitcher et al., 2013, p. 880). This indicates that the APBD spending studied has a high level of confidence. Several parameters of this statistical test result show that the Rap-Budget Spending method is sufficient to be used as a tool to evaluate the sustainability of DKI Jakarta's APBD spending.

\section{Conclusion}

In this study, the MDS method is able to be used to evaluate the sustainability of the DKI Jakarta's APBD spending, as well as to identify the factors that leverage the efforts to increase or optimize the spending, since the Government's spending has a significant influence on the economic growth of the Province, which for the last five years shows a trend that continues to slow from $6.53 \%$ in 2012 to $5.85 \%$ in 2016.

Based on the analysis, the DKI Jakarta's APBD spending in the last five years (2012-2016) with an average of $75.79 \%$, is on the average sustainability index of 47.64, which is categorized as "less sustainable". The main factors causing the less than optimal APBD spending is the spending of social assistance, grants, land acquisitions, and buildings and structures.

To ensure an optimal and sustainable spending of DKI Jakarta's APBD to maximize the positive impact of development felt by the community, it is suggested that the Government of DKI Jakarta develops policies related to the mechanism of providing social assistance to the community and community institutions/organizations. The quality of intensive coordination with vertical institutions and the surrounding regions in Jabodetabekjur cooperation also needs to be improved, to obtain an agreement on central and regional cooperation as well as inter-regional cooperation with the principle of equality and mutual benefit that currently has been done through the mechanism of grants. The land acquisition efforts have been hampered by the regulations that are difficult to implement, the recording of assets that have not been well organized, including differences in understanding with law enforcement officers, raising fears for the apparatus to implement it, need to get serious attention from the Government of DKI Jakarta to formulate an implementable policies but not contrary to the provisions of the existing laws and regulations, to ensure that the land acquisition does not hamper the physical development of the city's infrastructure. Similarly, for buildings and structures spending, it is necessary to simplify and accelerates the procurement process of construction goods and services in accordance with applicable laws and regulations.

\section{ACKNOWLEDGEMENT}

We would like to convey our gratitude and appreciation to Badan Pengembangan Sumber Daya Manusia Provinsi DKI Jakarta, which has provided the opportunities and facilitates this study. Badan Perencanaan Pembangunan Daerah Provinsi DKI Jakarta and Badan Pengelola Keuangan Daerah Provinsi DKI Jakarta which have compiled information of income, expenditure and financing in the financial statements as the form of government accountability to the public and Dinas Komunikasi dan Statistik which has published DKI Jakarta's APBD for the period of 2012-2016, enabling us to access the data published in the official website of DKI Jakarta. Last but not least, to the sources who have provided information for this study, as well as all parties who have provided support and facilitates, either in a technical support or content, enabling this study to be properly conducted as planned.

\section{REFERENCES}

Anitasari, M., \& Soleh, A. (2012). Pengaruh Pengeluaran Pemerintah terhadap Pertumbuhan Ekonomi di Provinsi Bengkulu. Ekombis Review, 117-127. Retrieved from http://jurnal.unived.ac.id/index.php/er/ article/view/139 
Bakeri, S., P., M. Y. J., Riani, E., \& Sutjahjo, S. H. (2012). Analisis MDS (Multi Dimensional Scalling) untuk Keberlanjutan Pengelolaan Air Lintas Wilayah: Studi Kasus DKI Jakarta. Jurnal Teknologi Lingkungan, 13(1), 13-23. Retrieved from http://ejurnal.bppt.go.id/index.php/ JTL/article/view/1401

Benacorry, M., \& Bachtiar, E. (2014). Analisis Manajemen Perubahan Aplikasi Penyusunan $A P B D$ di Pemerintah Provinsi DKI Jakarta. University of Indonesia. Retrieved from http://lib.ui.ac.id/naskahringkas/2016-06/ S57385-Miranti Benacorry

Duadji, N. (2013). Partisipasi Publik dalam Pengambilan Keputusan Anggaran Pendapatan dan Belanja Daerah (APBD) Provinsi Lampung. Jurnal Bina Praja, 5(3), 197-203. http://doi. org/10.21787/jbp.5.2013.197-204

Fauzi, A., \& Anna, S. (2005). Pemodelan Sumber Daya Perikanan dan Kelautan untuk Analisis Kebijakan. Jakarta: Gramedia Pustaka Utama.

Government Regulation Number 58 of 2005 on Regional Financial Management, Pub. L. No. 58 (2005). Indonesia.

Hakim, L., \& Wijayanti, A. (n.d.). Pengaruh Belanja Modal terhadap Pertumbuhan Ekonomi (Studi Kasus Kabupaten dan Kota di Pulau Jawa dan Bali). Jurnal Ilmiah Mahasiswa FEB Universitas Brawijaya, 3(1). Retrieved from http://jimfeb. ub.ac.id/index.php/jimfeb/article/view/1499

Haryanto, T. P. (2013). Pengaruh Pengeluaran Pemerintah terhadap Pertumbuhan Ekonomi Kabupaten/Kota di Provinsi Jawa Tengah Tahun 2007-2011. Economics Development Analysis Journal, 2(3), 148-158. http://doi. org/10.15294/edaj.v2i3.1989

Hidayat, A. S., \& Nalle, F. W. (2017). Analisis Pengaruh Belanja Pemerintah, Tenaga Kerja, dan Pendapatan Asli Daerah terhadap Pertumbuhan Ekonomi Regional Provinsi Jawa Timur Tahun 2010-2015. Jurnal Ekonomi Pembangunan, 15(1), 71-86. Retrieved from http://ejournal.umm.ac.id/index.php/jep/ article/view/4647

Hikmah, Yulisti, M., \& Nasution, Z. (2011). Analisis Indeks dan Status Keberlanjutan Peran Serta Wanita dalam Pengembangan Usaha Pengolahan Hasil Perikanan. Jurnal Sosial Ekonomi Kelautan Dan Perikanan, 6(1), 103-114. http://doi.org/10.15578/jsekp. v6i1.5758

Hill, H., \& Andrews, M. (2005). Reforming Budget ritual and Budget practice: The Case of Performance Management Implementation in Virginia. International Journal of Public Administration, 28(3-4), 255-272. http://doi. org/10.1081/PAD-200047319
Jenssen, P. D., Vråle, L., \& Lindholm, O. (2007). Sustainable Wastewater Treatment. Proc. International Conference on Natural Resources and Environmental Management and Environmetal Safety and Health, (December 2002), 1-17.

Kavanagh, P. (2001). Rapid Appraisal of Fisheries (Rapfish) Project: Rapfish Software Description (for Microsoft Excel). Vancouver: University of British Columbia.

Kuncoro, H. (2008). Variansi Anggaran dan Realisasi Anggaran Belanja Studi Kasus Pemerintah Daerah Provinsi DKI Jakarta.Jurnal Manajemen Teori Dan Terapan, 1(2), 126-143. Retrieved from https://e-journal.unair.ac.id/JMTT/ article/view/2362

Law of the Republic of Indonesia Number 23 of 2014 on Regional Government, Pub. L. No. 23 (2014). Indonesia.

Law of the Republic of Indonesia Number 29 of 2007 regarding Provincial Government of the Special Capital Region of Jakarta as the Capital of the Unitary State of the Republic of Indonesia, Pub. L. No. 29 (2007). Indonesia.

Nurmalina, R. (2008). Keberlanjutan Sistem Ketersediaan Beras Nasional: Pendekatan Teknik Ordinasi Rap-Rice dengan Metoda Multidimensional Scaling (MDS). Jurnal Agribisnis Dan Ekonomi Pertanian, 2(2), 65-88. Retrieved from http://journal.ipb.ac.id/index. php/jurnalagribisnis/article/view/6041

Persada, C., Sitorus, S. R. P., Marimin, \& Djakapermana, R. D. (2014). Penentuan Status Keberlanjutan Infrastruktur Perkotaan (Studi Kasus: Kota Bandar Lampung). Jurnal Sosek Pekerjaan Umum, 6(1), 17-27. Retrieved from http:// jurnalsosekpu.pu.go.id/index.php/sosekpu/ article/view/20

Pitcher, T. J. (1999). Rapfish, a Rapid Appraisal Technique for Fisheries, and Its Application to the Code of Conduct for Responsible Fisheries. FAO Fisheries Circular No. 947. Rome, Italy: Food and Agriculture Organization of the United Nations. Retrieved from http://www. fao.org/docrep/005/X4175E/X4175E00. HTM

Pitcher, T. J., Lam, M. E., Ainsworth, C., Martindale, A., Nakamura, K., Perry, R. I., \& Ward, T. (2013). Improvements to Rapfish: A Rapid Evaluation Technique for Fisheries Integrating Ecological and Human Dimensions. Journal of Fish Biology, 83, 865-889. http://doi.org/10.1111/ jfb. 12122

Pitcher, T. J., \& Preikshot, D. (2001). Rapfish: A Rapid Appraisal Technique to Evaluate the Sustainability Status of Fisheries. Fisheries Research, 49(3), 255-270. http://doi. 
org/10.1016/S0165-7836(00)00205-8

Provincial Government of DKI Jakarta. (2013). The Regional Government Financial Report (LKPD) of DKI Jakarta Province of 2012. Jakarta: Provincial Government of DKI Jakarta.

Provincial Government of DKI Jakarta. (2014). The Regional Government Financial Report (LKPD) of DKI Jakarta Province of 2013. Jakarta: Provincial Government of DKI Jakarta.

Provincial Government of DKI Jakarta. (2015). The Regional Government Financial Report (LKPD) of DKI Jakarta Province of 2014. Jakarta: Provincial Government of DKI Jakarta.

Provincial Government of DKI Jakarta. (2016a). The End-of-Term Accountability Report (LKPJ-AMJ) of DKI Jakarta Province of the Year 2013 to 2017. Jakarta: Provincial Government of DKI Jakarta.

Provincial Government of DKI Jakarta. (2016b). The Regional Government Financial Report (LKPD) of DKI Jakarta Province of 2015. Jakarta: Provincial Government of DKI Jakarta.

Provincial Government of DKI Jakarta. (2017). The Regional Government Financial Report (LKPD) of DKI Jakarta Province of 2016. Jakarta: Provincial Government of DKI Jakarta.

Puspitasari, R. (2013). Studi Penganggaran Berbasis Kinerja pada Pemerintah Provinsi Jawa Timur, Jawa Barat dan DKI Jakarta. Jejaring Administrasi Publik, V(2), 356-369. Retrieved from http://journal.unair.ac.id/ADMP@ studi-penganggaran-berbasis-kinerja-padapemerintah-provinsi-jawa-timur,-jawa-baratdan-dki-jakarta-article-9239-media-81category-8.html

Regulation of the Minister of Finance Number 258 of 2015 on the Procedure for Awarding and Imposing Sanctions on the Implementation of Expenditures of Ministries/Institutions, Pub. L. No. 258 (2015). Indonesia.

Regulation of the Minister of Home Affairs Number 21 of 2011 regarding the Second Amendment to the Regulation of the Minister of Home Affairs Number 13 of 2006 concerning Guidelines on Regional Financial Management, Pub. L. No. 21 (2011). Indonesia.

Regulation of the Minister of Home Affairs of the Repulic of Indonesia Number 13 of 2006 regarding Guidelines on Regional Financial Management, Pub. L. No. 13 (2006). Indonesia.

Rismunandar. (2016). Strategi Kebijakan Pemanfaatan Jasa Lingkungan Air Secara
Berkelanjutan di Taman Nasional Gunung Ciremai Kuningan - Jawa Barat. Jurnal Pengelolaan Sumberdaya Alam Dan Lingkungan, 6(2). Retrieved from http:// journal.ipb.ac.id/index.php/jpsl/article/ view/12677

Roy, G. G. (1982). The Use of Multi-Dimensional Scaling in Policy Selection. Journal of the Operational Research Society, 33(3), 239-245. http://doi.org/10.1057/jors.1982.49

Simarmata, D. A. (2007). Keberlanjutan Fiskal di Indonesia. Indonesian Economic Journal, 1-24. Retrieved from https://mpra.ub.unimuenchen.de/41344/

Sinaga, E. J. (2016). Analisis Rendahnya Penyerapan Anggaran Kementerian/Lembaga (K/L) dan Pemerintah Daerah. Jurnal RechtsVinding, 5(2), 261-274. Retrieved from http://rechtsvinding. bphn.go.id/view/?id=235\&isi=artikel

Statistics of DKI Jakarta Province (BPS Provinsi DKI Jakarta). (2017). Informasi Statistik Bulan Oktober 2017. Jakarta, Indonesia: Statistics of DKI Jakarta Province (BPS Provinsi DKI Jakarta). Retrieved from https://jakarta.bps. go.id/ backend/fileMenu/Infostat-BulanOktober -2017.pdf

Walundungo, G. A., Paendong, M., \& Manurung, T. (2014). Penggunaan Analisis Multidimensional Scaling untuk Mengetahui Kemiripan Rumah Makan di Manado Town Square Berdasarkan Kerakteristik Pelanggan. Jurnal de Cartesian, 3(1), 30-35. Retrieved from https://ejournal. unsrat.ac.id/index.php/decartesian/article/ view/3806

Widiatmaka, Munibah, K., \& Sitorus, S. R. P. (2015). Appraisal Keberlanjutan Multidimensi Penggunaan Lahan untuk Sawah di Karawang - Jawa Barat. Kawistara, 5(2), 113-131. http:// doi.org/10.22146/kawistara.7591

Wijayanto, H. (2015). Transparansi Anggaran Pendapatan dan Belanja Daerah (APBD) melalui Penerapan e-Budgeting (dalam Perspektif Teori Good Government). IJPA-The Indonesian Journal of Public Administration, 1(1), 72-88. Retrieved from http://journal. uta45jakarta.ac.id/index.php/admpublik/ article/view/79

Yogiesti, V., Hariyani, S., \& Sutikno, F. R. (2010). Pengelolaan Sampah Terpadu Berbasis Masyarakat Kota Kediri. Jurnal Tata Kota Dan Daerah, 2(341), 95-102. 